\title{
A Comparative Study of Valuation Variance and Accuracy between Nigeria and UK
}

\author{
James B. Effiong (M.SC, ANIVS, RSV) \\ Department of Estate Management \\ Cross River University of Technology, Calabar- Nigeria \\ E-mail address: jamesbassey4real@yahoo.com GSM: 07032544821
}

Keywords: Valuation, Variance, Accuracy, Inaccuracy, Standards, Causes, Nigeria.

\begin{abstract}
The study compared the level of valuation variance and inaccuracy between Nigeria and UK. In order to achieve the aim for the study, a survey method was employed using questionnaire administered on respondent estate surveyors and valuers in Calabar and Uyo metropolises. The study surveyed valuers opinions on the existence of valuation variance and inaccuracy, the possible causes and the margin of valuation error and data collected through questionnaire was analyzed using descriptive statistics to find the mean score, standard deviation and percentages. The findings from the study show that valuation variance and inaccuracy is high in Nigeria as compared to UK. The possible causes include lack of standards, lack of market data/comparables, lack of regulatory framework, methods/bases of valuation adopted, client's influence, inadequate training of valuers, imperfect knowledge of the property market, wrong assumptions on cost per square metre, lack of professional experience as well as failure to discipline valuers on cases of negligence with lack of standards ranked first with the highest frequency and mean score. The study concluded by recommending the creation of a central property database, adopting/enforcement of international valuation standards, enforcement of disciplinary measures for erring members on negligence and a defined acceptable margin of valuation error.
\end{abstract}

\section{INTRODUCTION}

Valuation is a core discipline of the Real Estate Surveying and Valuation profession in Nigeria and the world over and forms the foundation on which the real estate profession is built. Valuation plays a very important role in transactions in real assets for transfer of ownership, financing and credit, tax matters, investment advising, accounting, management control/records and decision making in investment performance measurement (Appraisal Institute, 2001 and McAllister, 1995). Therefore, professional valuation for any purpose ought to be accurate to provide dependable bases for decision making but valuation variance and inaccuracy is very worrisome and disappointing. The deviation between valuation and market prices is the degree of valuation inaccuracy while the deviation between two or more valuations on the same subject property made at the same time for the same purpose is valuation variance (Ibiyemi, 2013). However, it is noted that no two valuers carrying out valuation on the same property, given the same information will ever arrive at the same opinion of value (Ayedun, Oloyede, Iroham and Oluwunmi, 2011). The growing concern for the variance in valuation in Nigeria is something that needs to be given a serious attention, especially where the acceptable margin of error falls beyond acceptable limits. Ayedun, Oloyede, Iroham and Oluwunmi (2011) noted that the valuation process and the result from valuers had formed the subject of debate, argument and controversy in most parts of the world for the past two and a half decades.

In accepting the adoption of value ranges as a feature of the valuation practice, it is necessary to recognize that such ranges must relate to the amount achievable in the market (Boyd and Irons, 2002). The variance between valuation estimates produced by valuers in Nigeria and the predicted market prices has been subject of serious debate among the professionals, the academia and other valuation stakeholders. The competence of Nigerian valuers and the reliability of valuation opinion from the valuers has been the focus of such debate and discussion (Ayedun et al, 2011). To some 
extent, property valuations are seen to be uncertain (Carsbeg, 2002; Mallinson, 1994) in Skitmore et al (2007). Despite the fact that property values are usually reported as a single estimate or figure, instead of a range of figures, it is very uncertain. This is due to the surrounding market condition which is a normal characteristic from property to property and prevailing market conditions (Carsberg, 2002) in Skitmore et al (2007). The significance of inaccurate valuations was noted by Parker (1998) to adversely influence the valuer's character only if there may be a probability for valuation accuracy, which may lead to questioning why there is need for the valuation at all by clients. Again it can be seen that the problem of valuation inaccuracy can lead to damaging the confidence of the property market (Babawale, 2006). The implication of inaccuracy in valuations in Australia as noted by Parker (1998) is that there might be a threat to the valuation profession, the property development industry and the property market. But in Nigeria, the implications of valuation inaccuracy have been extended to include the individual valuer and by extension, the nation's economy as a whole (Udo-Akagha, 1985) in Ayedun, Ogunba and Oloyede (2012). Based on the reasoning that two or more valuers valuing the same property at the same time for the same purpose and the same data would not arrive at the same value, many commentators have wondered if estate valuers are interpreters or creators of values (Aluko, 1998). As the concern for valuation variance and inaccuracy continue to generate more debate, the consumers of valuation services may become weary and begin to question the reliability of the valuer's opinion of value. If this issue is not finally addressed, a widespread rejection of valuer's opinion of value may occur and impinge severely on the Nigerian valuation profession. This paper is aimed at comparing valuation variance and accuracy studies between Nigeria and UK.

\section{THE UK AND NIGERIA VALUATION PROFESSIONS}

All over the world, for a valuer to practice, he/she needs professional qualification. In the UK, the professional body that regulates the practice of real estate is the Royal Institution of Chartered Surveyors (RICS). For a valuer to carry out valuation in UK, he/she must be a chartered surveyor. Chartered surveyors are engaged in property valuations both in the private and public sectors. RICS is an independent body which is saddled with the responsibility of regulating property professionals and surveyors in UK and other countries of the world. Chartered surveyors carrying out valuation in UK are guided by valuation standards ("The Red Book- RICS Valuation Standards"). The Red Book contains RICS practice statement and guidance notes on valuation known as RICS Valuation Standards. These standards are mandatory to all RICS members and ensure that the standards are adhered to and comply with best practices in order to reduce the risk of negligence. RICS valuation standards align and comply with standards set by the International Valuation Standards Committee (IVSC).

In Nigeria, for a valuer to carry out property valuation, the valuer also needs professional qualification and must belong to a professional body. Unlike UK, Nigerian practice is controlled by two bodies namely; The Nigerian Institution of Estate Surveyors and Valuers (NIESV) otherwise known as the "Institution". The second is Estate Surveyors and Valuers Registration Board of Nigerian (ESVARBON) otherwise known as the "Board". While the Institution trains Estate Surveyors and Valuers, the Board regulates the practice of Real Estate profession in Nigeria. The NIESV valuation and guidance notes published in 2006 to guide valuers in Nigeria does not align with international valuation standards and therefore need to be upgraded to meet international standards.

\section{REVIEW OF LITERATURE}

The work of Hager and Lord (1985) pioneered the debate and criticisms over valuation accuracy as an estimate of market price and the methods used in carrying out property valuations. They conducted a survey of 10 surveyors they invited to carry out a valuation of two properties. They were provided with the same information and instructions and the values from their valuations show variance significantly. The valuation produced $\pm 10.6 \%$ and $\pm 18.5 \%$ which suggests that the 
level of accuracy in valuation is very low compared to $\pm 5 \%$ adopted benchmark (Hager and Lord, 1985; Ayedun, Oloyede, Iroham and Oluwunmi, 2011). In contributing to the debate, Adair et al (1996) pointed out that the major criticisms of valuation accuracy are the failure of property valuations to accurately reflect on the changing market conditions, demand and supply expectations.

Between 1975 and 1980, Brown (1985) studied 29 properties that their sales prices were known prior to recent valuation figures. By applying regression analysis the result showed a high correlation of $93.4 \%$ between valuation estimates and transaction prices, suggesting that accuracy level in valuation is high. Brown (1985) concluded that the sample size was however, too small to be used in drawing conclusions that are unbiased. Another study conducted by IPD/Drivers Jonas (1988) adopted regression analysis on 1,442 properties. Two valuations were carried out on each of the properties based on open market value two years preceding their sales. These samples were analyzed with regression analysis which was the procedure used by IPD/Drivers Jonas. This study shows a high level of correlation of $93.4 \%$ between valuation estimates and transaction prices of 93.4\% and suggests also that accuracy level in valuation is high (Adair et al, 1996; Ayedun et al, 2011; Ayedun et al, 2012). The study of IPD/Drivers Jonas (1988) was updated in 1990 with a sample size of 2,400 in order to test how market conditions in the 1980 s influence valuation. The findings from the study show that there was no increase in valuation variance in changing markets during that period. Their argument was that the property market was assessed by valuers to be accurate (Adair et al, 1996).

In contrast to the studies of Brown (1985) and IPD/Drivers Jonas (1990), Lizieri and Venmore-Rowland (1991) argued and questioned the findings of the two earlier studies which regression analysis was applied. They opined that extreme values used in the sample by the above authors could lead to a violation of one of the key assumptions of regression equation as the residual has a constant variance. They noted that if this assumption fail to hold, then the estimated coefficient of the variables are likely to be biased. They also noted that there are shortcomings in their regression based analysis and there is, however, a more fundamental difficulty with the regression-based defence of valuation.

In reaction to the criticisms the studies of Brown (1985) and IPD/Jonas (1988, 1990) generated, Matysiak and Wang (1995) conducted a study on the commercial property market prices and valuation with 317 set of properties with data provided by Jones Lang Wootton. Most of the valuations for these properties were conducted between three (3) and six (6) months prior to their sales date. They reported that the average absolute error provides an indication of the range of error for the whole sample of 317 properties. The average percentage error they noted should tend towards zero if there are no significant differences between under valuation and over valuation bias. Matysiak and Wang (1995) suggested that studies regarding agreement of valuations and prices cannot be addressed conclusively. They used standard deviation to analyze the result of 317 valuations and data sale prices from 1973 to 1991 and found out that the degree of confidence to achieve $\pm 10 \%$ sales price of the estimated valuation was just $30 \%$, which increases to $55 \%$ degree of confidence at $\pm 15 \%$ of the valuation and $70 \%$ at $\pm 20 \%$ of the valuation estimates.

Hutchison et al (1995) in Ayedun et al (2011; 2012) and Adair et al (1996) carried out a study in which they surveyed five national and five local valuers in each of the 14 centres of their study in UK. They asked valuers in both the national and local firms to carry out a valuation of retail, office and industrial properties hypothetically, having the same characteristics in their actual locations and lease covenants. They examined valuation variance rather than valuation accuracy and found differences in valuation variance between the five national and local valuation firms of $8.63 \%$ and $11.86 \%$ for the national and local firms respectively. They further discovered that over $80 \%$ of all the valuations produced a deviation from the mean of less than $20 \%$, which is a wider variance in valuation as compared to that which was suggested by Brown (1991) study. These results are 
subject to questioning as the valuers were not paid any fees and the properties used in their study were hypothetical.

McAllister (1995) conducted a study which involved transaction data of 30 properties sold by private treaty and 27 by informal tender from 1987 to 1992 . The data collected for this study was not sufficient to allow for the test of accuracy of the valuation based on different conditions of the market. The result of the study didn't support any higher degree of competence by valuers in predicting sale prices of properties. The author observed that for about half of the transaction $(56 \%)$, valuers were accurate within $10 \%$ of the sale prices and in the overall; the mean absolute percentage error was $15 \%$ while the average percentage suggests an error of $10 \%$. The study noted further that valuation accuracy has raised some complex methodological issues such as the measurement and potential impact of the lag period, the contamination of the price by the valuation and the fact that only successful transactions were analyzed. The researcher drew conclusion from his study that there is likely to be a problem of valuation error but that there is little evidence to suggest that valuation bias occurs.

Bretten and Wyatt (2001) investigated the causes of valuation variance in commercial property valuation for lending purpose in the UK via a questionnaire survey served on 220 respondents comprising valuers, property companies, financial brokers, institutional investors and lending authorities. The study revealed that the main causes of valuation variance impinge on the valuer's behavioural influence. They concluded that variation can enter the valuation process at any point or phase, starting with instructions from clients and negotiation of fees, and including the pressure put on the valuer in the statement of his opinion of value. The study concluded that variance in valuation is inevitable; therefore, the valuer's opinion of value should be expressed in a range of figures rather than a single point estimate.

Mokrane (2002) examined valuation variance and accuracy in UK, Germany, Sweden, France and Netherlands from 1990 to 2000. In France, 2,000 properties studied from1999 to 2000; 1,800 properties from 1997 to 2000 in Sweden; in Netherlands, 5,700 properties between 1999 and 2000; and 400 properties in Germany between 1997 and 2000. To test for accuracy, previous valuations were adjusted to reflect movements in the market, capital expenses which might have occurred between the date of valuation and the date of transaction and a conclusion reached that there exists only a short distance between transaction sales and adjusted valuations in the five respective countries, though estimates from valuation differed from sales price. In the case of valuation variance or consistency, the author found that in most of these countries, the degree of valuation variance was relatively low and the change-in-valuer effect was statistically significant.

Crosby et al (2003) also carried out a study in UK to find out if the IPD 2002 sales report on monthly index shows any evidence of known sales price prior to their date of completion of the transactions. The analysis showed a significant movement in the valuation which took place in the month before the transaction was completed. The second analysis compared the difference between valuations and sale prices for various updating periods to completion, 1, 2 and 3 months prior to completion. The update made before the date of completion shows a decrease in the level of accuracy in a rising market and increases in a falling market. This assumes that average valuations are lower than average sale prices, which was the case in the 2002 data. They concluded in their study by considering timing as an issue that makes it difficult to produce conclusive results on valuation and price differences.

Blundell and Ward (2008) studied valuation accuracy to determine the effects of market movements on sales valuation relationship. Their study covered a sample size of 775 property sales from 1973 to 1990 that were valued before by more than ten valuation groups. Their data was also collected from Jones Lang Wootton. The result suggested that the sales price of properties that were 
sold within the period of 1974 to 1990 was on a near average of 7\% which was higher than the valuation and that the standard deviation of the differences was slightly higher than $18 \%$. They observed that the distribution was not symmetrical considering the proportion of errors lying within $\pm 20 \%$ range. Their results further revealed that $6 \%$ of the valuations overestimated the sales price by $20 \%$ and about $9 \%$ of the valuations underestimated the sales price by $20 \%$. They concluded that valuations are marginally more accurate than might be expected, taking into consideration from both the theoretical perspective and in comparison with equivalent valuation in equity markets. They opined that valuations were on the average underestimates of the sale prices and this underestimation could be expected to be a function of the market performance.

The study into valuation accuracy and variance in Nigeria was first embarked on by Ogunba (1997) who examined accuracy of investment valuations, their variation and how they can be addressed. His study focused on Lagos and because there was no database for transactions in property, he requested 30 estate valuation firms in Lagos to conduct a valuation of two residential properties sold earlier and located at Victoria Island and Ikoyi (prime areas of Lagos). The valuation opinion from the 30 firms was subjected to statistical tests using regression/correlation analysis, mean deviation etc. The result shows valuations as not being good proxy for market prices for three good reasons. These include the variation between the sales prices and the valuations was more than the margin of valuation error of $\pm 5 \%$ adopted by him, the regression equation intercept was distinguished from the zero mark while the slope was distinguished from 1 also, the last reason being that the inter-quartile ranges were unacceptably wide (Ayedun et al, 2011; 2012).

Ogunba (2004) study focused on the demand for accuracy in valuations and surveyed 200 firms in Lagos and the data collected were analyzed using statistical tools such as range, interquartile range, mean deviation, regression analysis and analysis of variance (ANOVA). For the range and interquartile range test, He defined the standard of accuracy by a range not exceeding $\mathrm{N} 500,000$ as this seems to be the maximum range clients in Nigeria can accept. The interquartile range provides the range of the more accurate of valuations of $50 \%$ and for accuracy it should not be more than $\mathrm{N} 250,000$. These tests were done on five states and it can be seen that the ranges are much higher than that expected by clients he noted especially in Lagos. The second analysis was the mean deviation from the market price which Ogunba defined as the mean of the distances of the valuations from the actual market price. Ogunba measured accuracy by determining if the mean deviation from market prices exceeded $10 \%$ which he adopted as the acceptable limit of variance from the sales price. The result from his work shows that the deviations are very high and above the $10 \%$ adopted. In conclusion, Ogunba noted that there is a significant degree of inaccuracy in valuations in Nigeria and observed that the causes both come from the valuation practitioners and the educational background of the valuers.

Aluko (2004) conducted a study to find out how reliable valuations for mortgage purposes are. He examined if the open market valuations are a good proxy for prices in Lagos metropolis and interviewed 42 lending institutions and 59 estate surveying and valuation firms through stratified sampling. His methodology regressed the open market value for mortgage of each of the sampled properties onto its transaction prices. In order to test the reliability of mortgage valuations, he collected data for 121 open market sales relating to transactions on mortgaged residential properties from the Nigerian Deposit Insurance Corporation (NDIC), lending institutions and estate firms. The bank ordered a valuation of a mortgagor who was unable to redeem his mortgage to the lender on an open market basis before a sale of the collateral security. The valuation was carried out on the same basis as mortgage valuation executed before a loan is given. The data collected was from January 1994 to December 2002. The result shows that the relationship between the values and the prices of the properties sampled was $78 \%$ and it was significant at $p=0.0000$ and $61 \%$ of the prices accounted for inaccuracy in their values. He concluded that the evidence from his regression analysis shows that there is a relative degree of accuracy in the open market valuation for mortgages 
and that they are a good proxy for predicting market prices, although the accuracy is not as good as that obtained in UK, USA and Australia. Aluko et al (2004) also noted that value should be reported as a range rather than a single point estimate. They further opined that there is need for valuers to adopt statistical analysis in their valuation as this would help to improve valuation accuracy and reliable value prediction or estimation.

Aluko (2007) examined valuers judgment in residential property valuations in Lagos metropolis by a survey of 59 estate firms randomly selected in Ikoyi, Lagos. The firms were allowed to inspect and value a particular property and asked to rank the features of the property in order of importance especially their contributions in valuing the subject property. This study revealed that there was inconsistency among valuation firms in the interpretation of value influencing variables for the same property. He noted that valuation variance is inevitable and concluded that the differences in the opinion of value for the valuer's judgement must not be too wide if valuation is to be reliable.

Also, Ajibola (2010) examined the causes of valuation inaccuracy in Lagos Metropolis by a survey of 300 estate surveyors and valuers through questionnaires and interviews and 150 questionnaires were returned representing a response rate of $50 \%$. The data analysis was done using descriptive statistics. He also interviewed selected executive members of the valuation profession in Nigeria and 10 valuation lecturers. His result shows that $78.8 \%$ of the respondents relied on inhouse database for valuation assignments and reliance on in-house data source indicates that the valuers use information that may not be properly processed and this could in turn result in valuation inaccuracy. He noted that studies in UK, USA and Australia show acceptable range of valuation inaccuracy between $\pm 5 \%$ to $\pm 10 \%$ for UK and USA and $\pm 10 \%$ to $\pm 15 \%$ in Australia. On the contrary, Nigerian studies according to him produced outrageous figures by Ogunba and Ajayi (1998) of 33.43\% for Victoria Island property and 36.47\% for Ikoyi while Ajibola (2006) produced $\pm 24.82 \%$ for Ikoyi and $\pm 51.54 \%$ for Ojodu. He argued that valuation as presently carried out is not a good proxy for sale and mortgage transactions for properties in Lagos.

Furthermore, Ogunba and Iroham (2011) investigated more on the causes of valuation variance and inaccuracy in Nigeria in order to determine an acceptable margin of valuation error. Their study surveyed a total of 195 estate surveyors and valuers in Lagos Metropolis and 25 commercial banks in Nigeria. The sampling of the valuation firms was done with the use of stratified sampling technique. The response rates of $75.89 \%$ and $79.17 \%$ were achieved for the valuers and their clients. The findings revealed that valuation variance can be from $\pm 11.1 \%$ as suggested by the valuers and $13.16 \%$ as suggested by their mortgage clients in Nigeria. This result is higher than the ranges of $5 \%$ to $9 \%$ recommended by the UK courts for residential property investments.

Ayedun et al (2011a) researched on the perception of clients regarding the reliability of property investment valuations in Nigeria. They studied 24 commercial banks in Lagos and 50 property companies that form part of the major users of valuation reports and questionnaires were administered on them. The response rate of $62.5 \%$ for the banks and $64 \%$ for the property companies was achieved and data collected were analyzed using descriptive statistics. In order to determine the reliability of valuation estimates as perceived by clients, they were asked to give their impression of valuation estimates from valuers based on their own experiences. $60 \%$ of the banks show that valuers opinions of valuation figures were not reliable, $26.66 \%$ agreed that valuations are fairly reliable while $13.33 \%$ believed that valuations are absolutely reliable. On the other hand, $56.25 \%$ of the property companies believed valuations from valuers are unreliable while $15.65 \%$ considered that valuations are absolutely reliable and $28.125 \%$ sees it to be fairly reliable. From the above results, it can be concluded that clients are far from being satisfied with the reliability and accuracy of valuation opinions from their external valuers. For margin of error accepted, both the 
banks and property companies suggest a margin of $1 \%-5 \%$ representing $47 \%$ and $56.25 \%$ respectively. $40 \%$ of the banks went for $6 \%-10 \%$, and $13 \%$ for $11 \%-15 \%$ while $32.25 \%$ of the property companies went for $6 \%-10 \%$. They concluded that the majority of clients as represented by banks at $47 \%$ and property companies at $56.25 \%$ needed valuer's valuation estimates to be close as possible to the market prices of properties.

In another empirical study to verify the level of valuation accuracy in Nigeria, Ayedun et al (2011b) conducted an experiment by retrospective valuation of 12 residential properties which were sold between one and two months prior to the valuation date. The information about the sale prices was not made known to the valuers who did the valuation. The sample was made up of 45 estate firms by the use of stratified sampling and data obtained were analyzed using descriptive and inferential statistics. The analyzed results from the simulated valuation showed a range of differences between properties sale prices and estimates from valuations with N690,000,000 (six hundred and ninety million naira) differences for the $9^{\text {th }}$ property. The mean and standard deviations also revealed a high level of inaccuracy and none of the mean value fell within $30 \%$ of the sale prices. The mean deviation from market prices for all the sampled properties was $\pm 32.44 \%$ which represents a very high level of inaccuracy as compared to $\pm 5 \%$ adopted by Hager and Lord (1985). It shows that market prices were not interpreted by valuers with reasonable measure of accuracy. This revealed that only $4.4 \%$ of the valuation estimates equals to the sale prices, $8.3 \%$ fell within $\pm 5 \%$ margin of error while $15.2 \%$ fell within the margin of error range of $\pm 10 \%$. They noted that if $\pm 10 \%$ is set as the acceptable margin of error as in Hager and Lord (1985), then it means that valuations falling within the acceptable margin of valuation error were $15.2 \%$ only. This was below what Baum et al (2000) was able to achieve at 90\% and 59\% for their study earlier in 1983.

\section{Establishment of Acceptable Margin of Error}

This debate started in the UK courts where cases regarding the acceptable margin of error have been decided. The issue of valuation variance outside the scope of Nigeria had involved the courts in the determination of the acceptable margin of valuation inaccuracy or error. Watkins J. in Singer Friedlander Ltd v John D. Wood \& Co [1977] 2 EGLR 84 ruled that: The valuation of land by trained, competent and careful professional men is a task which rarely, if ever, admits of precise conclusion. Often beyond certain well-founded facts so many imponderables confront the valuer that he is obliged to precede on the basis of assumptions. The valuer should therefore not to be blamed for arriving at a value with some errors. If for instance, experienced two men were giving the same assignment, they may both arrive at different results and no one can justify that any one of them is lacking in competence, reasonable care or less integrity in carrying out his job. He noted further that valuation is an art and not a science. Watkins $J$ in summarizing the evidence by the expert witness said "the permissible margin of error to be generally accepted is $10 \%$ either side of the figure which can be said to be the right figure. He stated further that 15\% or a little more either way can be accepted as permissible margin of error in exceptional circumstances" (Parker, 1988, p.6; Ogunba and Iroham, 2011, p.56). However, the court accepted $\pm 10 \%$ in respect of a valuation of a large rural site intended for residential development. They adopted $\pm 15 \%$ for commercial properties as seen in the case of Corisand Investment Ltd v Druce \& Co [1978] 2 EGLR 86 (Ajibola, 2010). Another trial judge accepted a permissible margin of error of $15 \%$ either side of a bracket of value in the case of Private Bank and Trust Co. v S (UK) Ltd [1983] (Ogunba and Iroham, 2011). In Nigeria, there has been no singular report on any case decided by the Nigerian courts in respect to this subject from previous studies within Nigerian context.

In comparing the studies in the above literature from UK and Nigeria, it can be seen that most findings from those studies are common in their view on valuation variance and inaccuracy. There is still no definitive conclusion on the subject of valuation variance and level of accuracy as they hold divergent views about the subject matter. Many scholars in these countries for example Hager and Lord (1985), Matysiak and Wang (1995), McAllister (1995), Lizieri and Venmore-Rowland 
(1991), Hutchison et al (1995), Blundell and Ward (2008), Ogunba (1997; 2004), Ajibola (2010), Ogunba and Iroham (2011) and Ayedun et al (2011b) all argued that valuations are not accurate. In contrast to these studies, authors like Brown (1995), IPD Drivers Jonas (1988), Mokrane (2002), and Aluko (2004) argued in the opposite that there is high degree of valuation accuracy and as such they are good proxy for market prices. On the acceptable margin of error, UK studies show a range of $\pm 5 \%$ to $\pm 10 \%$ while that of Nigeria is yet to be decided though most studies adopted a margin of $\pm 5 \%$ to $\pm 10 \%$ provided by the UK courts.

\section{METHODOLOGY}

The research design approach adopted for this study is the descriptive research design and the survey method used to collect data for the study. Structured questionnaires were administered on respondents for collection of primary data. A 5-points Likert scale (where 5=strongly agree, $4=$ agree, $3=$ undecided, $2=$ disagree, and 1=strongly disagree) was used to rank the response from respondents. The study surveyed 50 Estate Surveying and Valuation firms in Calabar and Uyo in Cross River and Akwa Ibom States. A simple random sampling was used in selecting the firms. The questionnaires were administered on them on the existence of valuation variance and inaccuracy, possible causes of valuation variance and inaccuracy and acceptable margin of valuation error. 38 questionnaires were completed and returned achieving a response rate of $76 \%$. All the estate firms are duly registered with the Nigerian Institution of Estate Surveyors and Valuers (NIESV) and the Estate Surveyors and Valuers Registration Board of Nigeria (ESVARBON) which are the regulatory bodies in Nigeria. Data collected from the respondents were analyzed using statistical tools. The required test involved the determination of percentiles, means score and standard deviation and used to analyze participant's background and the questionnaires to determine the significance of ranked parameters through Statistical Packages for Social Sciences (SPSS) statistics 20.0 software.

\section{RESULTS AND DISCUSSION}

Descriptive Results of Characteristics of Respondents

\begin{tabular}{|lr|l|lr|l|}
\hline Variables & F & \% & Variables & F & \% \\
\hline & & & Age & & \\
Gender & & & 20-30 years & 23.7 \\
Male & 28 & 73.7 & 31-40 years & 17 & 44.7 \\
Female & 10 & 26.3 & 41-50 years & 6 & 15.8 \\
Years of Experience & & & 50-60 years & 6 & 15.8 \\
1-5 years & 16 & 42.1 & Academic Qualification & & \\
6-10 years & 11 & 28.9 & OND & 1 & 2.6 \\
Above 10 years & 11 & 28.9 & HND & 17 & 44.7 \\
Professional Qualification & & & BSC/B.Tech & 16 & 42.1 \\
Probationer & 15 & 39.5 & M. SC & 4 & 10.5 \\
Graduate & 8 & 21.1 & Age of Firm & 10 & 26.3 \\
Associate below 10 years & 10 & 26.3 & 1-5 years & 10 & 26.3 \\
Associate above 10 years & 5 & 13.2 & 6-10 years & 18 & 47.4 \\
\hline
\end{tabular}

F $=$ Frequency

From the table above, it can be seen that majority of the estate surveyors and valuers were males and they dominate in practice with a population of $73.7 \%$ while the female gender has only $26.3 \%$. The age of the respondents was also considered significant and it shows $23.7 \%$ fall within the age bracket of $20-30$ years, $44.7 \%$ for $31-40$ years, $15.8 \%$ for $41-51$ years and $51-60$ years respectively. Experience of the respondent's plays an important role in valuation accuracy and from the above table, $42.1 \%$ have $1-5$ years of experience, $28.9 \%$ for $6-10$ years, and $28.9 \%$ have above 
30 years of experience. In terms of academic qualification, $2.6 \%$ have Ordinary National Diploma (OND), 44.7\% Higher National Diploma (HND), 42.1\% Bachelor's degree and 10.5\% have Master's degree. The professional qualification of each respondent was also measured which shows 39.5\% for Probationers, 21.1\% for Graduates, 26.3\% for Associates below 10 years and 13.2\% for Associates above 10 years. On the average, only $40 \%$ of the study population are registered with the professional body. Finally, the age of the firm the respondents work with was considered and the result shows that $26.3 \%$ firms had been in existence between $1-5$ years and $6-10$ years and $47.4 \%$ above 10 years.

Table 1: Existence of Valuation Variance and Inaccuracy in practice

\begin{tabular}{llllllllll}
\hline Variables & & SA & A & U & D & SD & Mean score & $\begin{array}{l}\text { Std. Error of } \\
\text { mean }\end{array}$ & $\begin{array}{l}\text { STD. } \\
\text { Dev. }\end{array}$ \\
$\begin{array}{l}\text { Existence } \\
\text { variance }\end{array}$ & of & 16 & 20 & 2 & - & - & 4.3684 & 0.09557 & 0.58914 \\
\hline
\end{tabular}

SA=Strongly Agree, A=Agree, $\mathbf{U}=$ Undecided, D=Disagree and SD=Strongly Disagree Source: Field Survey, 2103

Results from the study have shown that valuation variance and inaccuracy exist within the Nigerian valuation practice as shown by the respondents. $42.1 \%$ strongly agreed and $52.6 \%$ agreed with this which represent $94.6 \%$ acceptance with a mean score of 4.3684 and a standard deviation of 0.58914 .

Table 2: Possible Causes of Valuation Variance and Inaccuracy.

\begin{tabular}{|c|c|c|c|c|c|c|c|c|c|}
\hline Variables & $\mathrm{SA}$ & $\mathrm{A}$ & $\mathrm{U}$ & $\mathrm{D}$ & SD & $\begin{array}{l}\text { Mean } \\
\text { score }\end{array}$ & $\begin{array}{l}\text { Std. Error } \\
\text { of mean }\end{array}$ & STD. Dev. & Rank \\
\hline Lack of standards & 17 & 16 & 3 & 1 & 1 & 4.2368 & 0.14817 & 0.91339 & $1^{\text {st }}$ \\
\hline $\begin{array}{l}\text { Lack of market } \\
\text { data/comparables }\end{array}$ & 14 & 20 & - & 3 & 1 & 4.1316 & 0.15629 & 0.96341 & $2^{\text {nd }}$ \\
\hline $\begin{array}{l}\text { Lack of } \\
\text { regulatory } \\
\text { framework }\end{array}$ & 11 & 22 & 2 & 3 & - & 4.0789 & 0.13271 & 0.81809 & $3^{\text {rd }}$ \\
\hline $\begin{array}{l}\text { Method/basis } \\
\text { adopted }\end{array}$ & 14 & 15 & 3 & 2 & 4 & 3.8684 & 0.20717 & 1.27705 & $4^{\text {th }}$ \\
\hline $\begin{array}{l}\text { Client's } \\
\text { influence }\end{array}$ & 13 & 16 & 1 & 4 & 4 & 3.7895 & 0.21388 & 1.31843 & $5^{\text {th }}$ \\
\hline $\begin{array}{l}\text { Inadequate } \\
\text { training }\end{array}$ & 8 & 21 & 4 & 3 & 2 & 3.7895 & 0.16933 & 1.04385 & $5^{\text {th }}$ \\
\hline $\begin{array}{l}\text { Imperfect } \\
\text { knowledge of } \\
\text { property market }\end{array}$ & 6 & 22 & 5 & 5 & - & 3.7632 & 0.14329 & 0.88330 & $6^{\text {th }}$ \\
\hline $\begin{array}{l}\text { Assumptions on } \\
\text { cost per square } \\
\text { metre }\end{array}$ & 11 & 16 & 4 & 4 & 3 & 3.7368 & 0.19844 & 1.22329 & $7^{\text {th }}$ \\
\hline $\begin{array}{ll}\text { Lack } & \text { of } \\
\text { experience } & \end{array}$ & 10 & 17 & 2 & 6 & 3 & 3.6579 & 0.20407 & 1.25798 & $8^{\text {th }}$ \\
\hline $\begin{array}{l}\text { Failure to } \\
\text { discipline valuers } \\
\text { on negligence }\end{array}$ & 8 & 18 & 5 & 3 & 4 & 3.6053 & 0.19792 & 1.22009 & $9^{\text {th }}$ \\
\hline
\end{tabular}




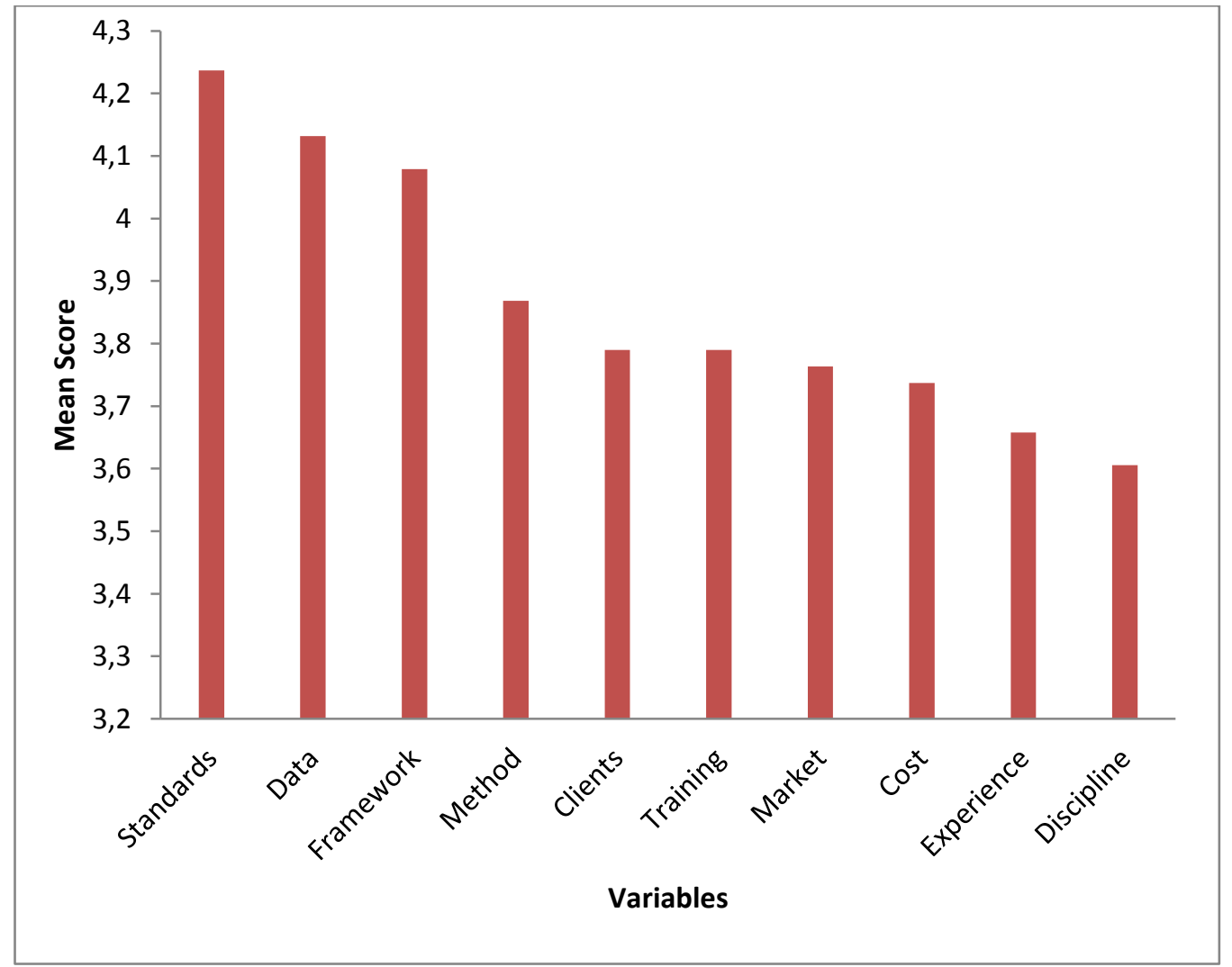

Fig. 1: Bar Chart representation of results on the possible causes of valuation variance and inaccuracy

Table 3: Acceptable Margin of Error

\begin{tabular}{lll}
\hline Variables & Frequency & Percentage \\
$\pm 5 \%$ & 16 & $\mathbf{( \% )}$ \\
$\pm 10 \%$ & 11 & 45.7 \\
$\pm 15 \%$ & 4 & 31.4 \\
$\pm 20 \%$ & 3 & 11.4 \\
Above $20 \%$ & 1 & 8.6 \\
Total & $\mathbf{3 5}$ & 2.9 \\
\hline
\end{tabular}

Source: Field Survey, 2103

Sampled opinion from professional valuers in Nigeria shows that for valuation to be accepted as been accurate; the error margin should be between $\pm 5 \%$ to $\pm 10 \%$ as indicated above by $45.7 \%$ and $31.4 \%$ of the respondents supporting this margin. Any valuation falling beyond this range will not be reliable.

The findings from the study revealed that valuation variance and inaccuracy exist within the Nigerian valuation profession as no two valuers can arrive at the same value opinion. It also shows that continuous variation in valuation will increase the rate of litigation on valuation matters. The possible causes of valuation variance and inaccuracy were seen to include lack of standards, lack of market data/comparables, lack of regulatory framework, methods/bases of valuation adopted, client's influence, inadequate training of valuers, imperfect knowledge of the property market, wrong assumptions on cost per square metre, lack of professional experience as well as failure to discipline valuers on cases of negligence. Among the causes of valuation variance and inaccuracy identified above, lack of standards was ranked first with the highest frequency and mean score. 


\section{CONCLUSION}

For valuations carried out to be accepted, it is expected that the valuation report procedure by a professional and registered valuer whose honesty, integrity, qualification and experience are appropriate to the valuation instruction. The valuer must therefore adhere to the code of professional ethics, conducts and show transparency. The methodology adopted however, will depend on the professional judgement of the valuer based on the circumstances surrounding the valuation to be carried out. Findings from this study have shown that valuation variance is inevitable. To resolve the problem of valuation variance and inaccuracy in Nigerian valuation practice, it is therefore the duty of both the practitioners including The Nigerian Institution of Estate Surveyors and Valuers, the Estate Surveyors and Valuers Registration Board of Nigeria and even the academia to develop measures that would ensure valuation accuracy in practice. This is because the confidence of valuation clients lies on the opinion of value provided by valuers and if this is not reliable, the confidence would be lost. Findings also from the review of literature from studies in Nigeria have indicated high level of valuation variance and inaccuracy as compared to that of UK, which shows that valuers do not interpret market values accurately. Among the possible causes of valuation variance and inaccuracy in Nigeria, lack of valuation standards was ranked highest. It is therefore the duty of NIESV and ESVARBON to upgrade the 2006 NIESV valuation standards and guidance notes to meet with international standards and also align with the International Valuation Standards Committee (IVSC) like that of UK. ESVARBON should also put in place ways of monitoring and enforcing compliance of the standards. A property data bank where information regarding previous transactions will be kept, published and updated periodically should be created. Valuers should avoid clients influencing them with incentives and be independent in reporting their value opinion. There should be enforcement of disciplinary measures for erring members on negligence. There should be strong advocacy for specialization in real estate practice to avoid practitioners who are not competent enough in valuation carry out valuation. An acceptable margin of valuation error should be well defined by the professional body in Nigeria as done by its counterparts in other parts of the world.

\section{References}

[1] Adair, A., Hutchison, N., MacGregor, B., McGreal, S., and Nanthakumaran, N. (1996). An analysis of valuation variance in the UK commercial property market: Hager and Lord revisited. Journal of property valuation and Investment, 14 (5), 34-47.

[2] Ajibola, M. O. (2010). Valuation inaccuracy: An examination of the causes in Lagos Metropolis. Journal of Sustainable Development, 3 (4), 187-193.

[3] Aluko, B. T. (1998). Property valuation: Are Estate Surveyors and Valuers interpreters or creators of value? The Estate Surveyor and Valuer, 21 (2), 9-17.

[4] Aluko, B. T., Ajayi, C. A., and Amidu, A. R. (2004). The Estate Surveyors and Valuers and the Magic Number: A point estimate or range of value. International Journal of Strategic Property Management, 8 (3), 149-162.

[5] Aluko, B. T. (2004). Reliability of Mortgage Valuation for Institutional Lending in Nigeria. International Journal of Strategic Property Management, 8 (4), 193-203.

[6] Aluko, B.T. (2007). Examining valuer's judgment in residential property valuations in metropolitan Lagos. Journal of property Management, 25 (1), 98-107.

[7] Ayedun, C. A., Oloyede, S. A., Iroham, O. C., and Oluwunmi, A. O. (2011). Clients' perception of the reliability of property investment valuation in Nigeria. Mediterranean Journal of Social Sciences, 2, (3), 479-486.

[8] Ayedun, C. A., Ogunba, O. A., and Oloyede, S. A. (2011). Empirical verification of the accuracy of valuation estimates emanating from Nigerian valuers: A case study of Lagos Metropolis. International Journal of Marketing Studies, 3 (4), 117-128. 
[9] Ayedun, C. A., Oloyede, S. A., and Durodola, O. D. (2012). Empirical study of the causes of valuation variance and inaccuracy in Nigeria. Journal of International Business Research, 5 (3), 71-79.

[10]Babawale, G. K. (2006). The growing concern over valuation accuracy in Nigeria. Journal of Land Use and Development Studies, 2 (1), 1-11.

[11]Blundell, G. F., and Ward, C. W. R. (2008). The accuracy of valuations- Expectations and Reality. Working papers in Real Estate and Planning. Henley Business School, University of Reading. URL: http://www.reading.ac.uk/rep/fulltxt/1408.pdf (Assessed 4th March, 2013).

[12]Boyd, T., and Irons, J. (2002). Valuation variance and negligence: The importance of reasonable care. Pacific Rim property Research Journal, 8 (2), 107-126.

[13]Bretten, J., and Wyatt, P. (2001). Variance in commercial property valuations for lending purposes: An empirical study. Journal of Property Investment and Finance, 19 (3), 267-282.

[14]Brown, G. (1985). Property investment and performance measurement: A reply. Journal of Property Valuation and Investment, 4 (1), 33-44.

[15]Crosby, N., Devaney, S., Key, T., and Matysiak, G. (2003). Valuation accuracy: Reconciling timing of the valuation and sale. Paper presented at the European Real Estate Society, Helsinki-Finland. URL:

http://citeseerx.ist.psu.edu/viewdoc/download?doi...1...\%20\%20United\%20States (Assessed $3^{\text {rd }}$ March 2013).

[16]Hager, D. P., and Lord, D. J. (1985). The property market, property valuations and performance measurement. Journal of Institute of Actuaries, 112, 19-60.

[17] Ibiyemi, A. O. (2013). Market Risks Consideration by Commercial Property Investors and Valuers in Nigeria: The Critical Issues. A $27^{\text {th }}$ Inaugural Lecture of Lagos State Polytechnic, Ikorodu, Lagos. August 14, 2013.

[18]Lizieri, C., and Venmore-Rowland, P. (1991). Valuation accuracy: a contribution to the debate. Journal of property Research, 8 (2), 115-122.

[19] Matysiak, G., and Wang, P. (1995). Commercial Property Market Prices and Valuations: Analyzing the correspondence. Journal of property Research, 12 (3) 181- 202.

[20] McAllister, P. (1995). Valuation Accuracy: A Contribution. Journal of property Research, 12 (3), 203-216.

[21] Mokrane, M. (2002). Valuations: Standards, Accuracy and Consistency. Paper presented at the IPD European Property Strategy Conference, Wiesbaden. URL: http://www.biis.info/uploads/media/Valuation___Standards_-_Mahdi_Mohkrane.pdf (Assessed 3rd March 2013).

[22] Ogunba, O.A., and Ajayi, C.A. (1998). An Assessment of the Accuracy of Valuations in the Residential Property Market in Lagos. Journal of the Nigerian Institution of Estate Surveyors and Valuers, 1 (2), 203-216.

[23] Ogunba, O.A. (2004). The demand for accuracy in valuations: the case of Nigeria. Paper presented at the International Symposium on Globalization and Construction, Thailand. Assessed April 2, 2013 from http://www.irbnet.de/daten/iconda/CIB6046.pdf

[24] Ogunba, O. A., and Iroham, C. O. (2011). A Search for an Acceptable Margin of Valuation Error: A case study of valuers and their clients in Nigeria. Sri Lankan Journal of Real Estate, 4, pp. 54-73.

[25]Parker, D. (1998). Valuation accuracy: an Australian perspective. Paper presented at the 4th Pacific Rim Real Estate Society Conference, Perth. URL: http://www.prres.net/proceedings/proceedings1998/Papers\%5CPark8Bi.PDF (Assessed 23 ${ }^{\text {rd }}$ February 23, 2013).

[26] Skitmore, R. M., Irons, J. J., and Armitage, L. A. (2007). Valuation accuracy and variation: A Meta analysis. URL:http://eprints.qut.edu.au/9485/1/9485_1.pdf (Assessed 8th February 2013). 